\title{
A Study on the Effects of the Consumer Lifestyles on Sustainable Consumption
}

\section{Dr. Hatice Aydın}

Muş Alparslan University

\section{Dr. Sevtap Ünal}

Atatürk University

\begin{abstract}
In this study,it is aimed to examine the impact of consumers' lifestyles on sustainable consumption trends. Life style is an individual's activities, interests and ideas about various issues. Consumers make consumption under the influence of these dynamics. Life style has an important place in the individual's consumption decisions. Sustainable consumption is a ethical consumption which correspond future generations needs and capabilities without the ethical barriers. But sustainable consumption is a hard progress which is effected by many factors. One of the factors is individual's life styles. Hence this study aimed to investigate whether there is an impact of consumer's life styles on sustainable consumption.According to result of survey which has been done at Erzurum/Turkey on 350 people, it has been determined that consumers' life styles have an impact on their sustainable consumption trends. The consumers who are innovators andthinkers carry more information about environmental problems and have more positive attitude. However thinkers and believers make more sustainable consumption.
\end{abstract}

Keywords: Sustainable Consumption, Lifestyle. 


\section{INTRODUCTION}

In today's world, people witness rapid changes. Thanks to the developments in technology, production methods have changed, and industrialization has advanced. The aim of all advancements is to raise the quality of life and facilitate the way people live. Little has been taken into account, though, concerning that these advancements would have a price to pay. This price is the negative influence on natural resources accompanied by the consumption increasing with production. As a result, a certain amount of imbalance is observed on resource consumption, and ecological destruction has been increasing steadily.

The issue of sustainability was suggested to overcome the problems stemming from the consumption of natural resources. To this end, such concepts as green consumption, environmental consumption, and ecological consumption were emphasized initially. Following these progresses, the concept of sustainable development gained importance. Sustainable development is a kind of development which enables meeting the current demands without threatening the possibility of meeting the demands of next generations. Sustainable development has been discussed in many conferences. Despite these discussions, environmental problems still could not be eliminated. Therefore, governments and businesses developed many policies to spread sustainable development. However, these efforts remained only in the form of sustainable production. As the fact that consumer efforts are required to create a sustainable world has been acknowledged, an inclination towards sustainable consumption has emerged, and a lot research has focused on this subject.

Sustainable consumption refers to meeting the demands of goods and services without threatening the demands of next generations. As for life style, it refers to the answer given to the question "How does a person live?. Life style is influenced by an individual's experiences, demographic attributes, attitudes, and characteristics. Therefore, different characteristics and experiences create different life styles which result in different consumption habits. Life style refers to what a person consumes in what way and in what amount. Thus, consumption by taking into account or ignoring natural resources must be the result of people's life styles. However, there is no study in the literature dealing with both sustainable 
consumption and life styles. The assumption that life style has an important role in sustainable consumption is the main reason for conducting the present study. The study has two sections. The first section gives information about life style and consumption. The second section deals with a survey conducted in the central district of Erzurum province as well as its results.

\section{THEORETICAL FRAMEWORK AND LITERATURE REVIEW}

\subsection{Sustainable Consumption}

Sustainability provides the basis of sustainable consumption. Sustainability refers to replacing renewable resources with nonrenewable ones and ensuring that our actions do not pose a threat to earth's life (Schaefer and Crane, 2005). Sustainability is an old phenomenon, but it is new as a concept. What has led to the emergence of sustainability as a concept is global pollution. Pollution started in the 16th century as a result of industrialization. The first pollution emerged in Britain and spread over the continental Europe and then the North America (Pearce, 1994).

Sustainable consumption was accepted as the pre-requisite of sustainability in the World Summit of Sustainable Development held in Johannesburg in 2002. Afterwards, a research and communication network (SCORE) was formed within the body of the 6th Framework Programme by the European Union. In 2005, studies for Collaborating Centre on Sustainable Consumption and Production (CSCP) (10Year Framework Programme for Sustainable Consumption and Production-Marrakech Process) were initiated with the collaboration of the United Nations Environment Programme (UNEP) and the Wuppertal Institute. Turkish government has paid a considerable attention to environment programmes since the 1930s. The Constitutional Law of 1982 covers an article regarding environmental problems: "It is the duty of the State and citizens to improve the natural environment, to protect the environmental health and to prevent environmental pollution" with the belief that a holistic approach would resolve environmental problems gaining importance each day. Furthermore, Environmental Law no. 2872 dated 1983 and all the development plans following the 3rd Development Plan aimed at dealing with environmental problems on a schedule. In this sense, today many organizations are operating in Turkey in accordance with

Inquiry

2015/2

135 
the environmental regulations. However, considering the history of sustainable consumption, it is clear that a sustainable world could not be thoroughly created in Turkey due to various reasons (Göksu, 1997).

Both national and international literature on sustainable consumption indicates that the studies generally focus on the demographic attributes of sustainable consumers. Zimmer and et al. (1994) and Straughan and Robert (1999) revealed that young people, women, people with higher educational levels, and people with high income levels are more environment-friendly than elderly people, men, people with lower educational levels, and people with lower income levels respectively. Similarly, the relationships between environmental knowledge and sustainable consumption attitude were examined. Laroche and et al. (2001) and Haron and et al. (2005) proved that there is a relationship between environmental knowledge and sustainable consumption. They found out that people engage in sustainable consumption more as their level of knowledge increases. There are also various studies exploring the relationship between consumers' psychographic characteristics and sustainable consumption. Özkul (2008) focused on the relationship between simple life style and consumption behavior, reported that sustainable consumption behaviors of consumers fall into two categories: value and environment-oriented behaviors, and noted that value-oriented behaviors are more important for people than environment-oriented behaviors. Kımıloğlu (2008) aimed at exploring the attitudes and behaviors towards factors influential on adopting sustainable consumption and simplification in consumption as a life style. That study concluded that consumers do not thoroughly adopt sustainable and simplified consumer behaviors as a life style. Ginsberg and Bloom (2004) asserted in their study that there is a group of consumers who are more eager to be environment-friendly. They also noted that consumers fall into different categories such as True Blue Greens, Sprouts, Grousers, and Basic Browns. According to them, Sprouts do not display a consistent attitude towards environmental issues though they pay attention to protecting the environment, and Grousers and Basic Browns tend to be indifferent to environmental issues.

\subsection{Lifestyle}

Life style is a broad concept referring to what people do, what is their motivation for their actions, and what those behaviors mean 
to other people (Blackwell and et al., 2001). Life style was put forward by Max Weber. Weber defined the term as differences between social groups (Kesiç and Rajh, 2003). Previous experiences, culture, demographic attributes, economic conditions, and values of consumers have an influence on their lives. Activities, attitudes, interests, and expectations of consumers are formed by aforementioned factors (Odabaşı and Barış, 2002). Measurement methods which are most frequently used in life style studies are as follows: Activities, Interests and Ideas, Rokeach Values System, Values List, Values and Life Styles (VALS), and Values and Life Styles 2 (VALS2). VALS2 was employed in this study to measure the life styles of the participants. There is some information about the scale below.

VALS was developed by Stanford Research Institute in 1980. A survey containing 800 questions about demographic characteristics, activities, financial situations, and product consumption styles were prepared in VALS research, and the basis of life style method was laid (Lin, 2003). Through the late 1980s, VALS2 was developed since VALS had been considered substandard to estimate consumer behaviors (Piirto, 1991). 400 questions were prepared to estimate consumer behaviors by VALS2 (Lin, 2003). Thanks to this scale, 8 life style segments were determined as follows:

Innovators comprise of inquisitive, active, successful, and sophisticated people with leadership characteristics who are wellinformed of new ideas and technologies and who buy products and services reflecting the characteristics of high social class.

Thinkers comprise of mature and calm people who value knowledge and world affairs, order, and responsibility and who make comprehensive research before making decisions.

Achievers comprise of in-control individuals whose social lives center on family, career, and success and who are active in market and are attached to premium products and services to prove their success.

Experiencers comprise of young people who like the new, offbeat, and risk and who spend much of disposable income on clothes, fashion, fast-food, music, movies, and cinema.

Believers comprise of conservative individuals who value 
family, religion, and social rules and do not spend on the things they do not need.

Makers comprise of self-sufficient individuals who are committed to traditions and family and whose interests, except for child-raising, home-mechanics, hands-on activities, and vegetable growing, are rather undeveloped.

Strivers comprise ofimage-conscious individuals who are attached to fashion products and entertainment and other consumers' opinions and who consider money as the source of success.

Survivors comprise of individuals with low income and educational level who are old, non-communicative, and without strong social relations. They do not spend on luxury due to their low income levels (Strategic Business Insights, 06.07.2012).

\section{STUDY DETERMINING THE RELATIONSHIP BETWEEN LIFE STYLE AND SUSTAINABLE CONSUMPTION}

\subsection{Purpose, Scope, and Limitations of the Study}

World's resources are limited and decreasing. Consumption models and life styles of the consumers change with the developing world as well. Current consumers demand many things such as suitability, quality, functionality, difference, and convenience all at once. Meeting these demands without threatening environment and human health and making sacrifices from people's life styles will result in benefits for everyone at community, business, and consumer levels. Determining the conditions leading to the emergence of sustainable consumption and the factors that have an influence on it will contribute much to both business and academic circles. The fact that there was no study exploring the relationship between life styles and sustainable consumption and the aforementioned importance of the issue led to this study aiming to explore the relationship between sustainable consumption and life styles. Another aim of the study is to explore the relationship between consumer attitudes to environmental protection and sustainable consumption tendencies. Consumers whose ages were over 18 and who were living in the central district of Erzurum province were included in the study. The life styles and the sustainable consumption behaviors of the consumers were not 
evaluated in terms of any brand or product. Therefore, the results cannot be generalized by product group, brand, or region.

\subsection{Research Hypotheses and Model}

The study model determined based on the aim of the research was shown in Figure 1

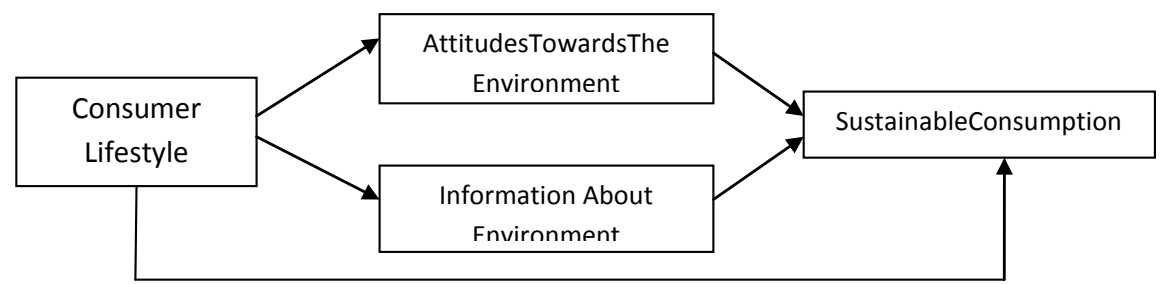

Fiqure 1: Research Model

The input variable of the research model is life styles while intermediate variables are environmental attitude and knowledge. Output variable is sustainable consumption tendency. Based on the research model, the hypotheses of the research are given below:

H1: Consumer lifestyle is effective on information about environment. $\mathrm{H} 2$ : Consumer lifestyle is effective on attitudes towards the environment. H3: Information about environment is effective on sustainable consumption.

H4: Attitudes towards the environment areeffective on sustainable consumption.

H5: Consumer lifestyle is effective on sustainable consumption.

\subsection{Research Methodology}

The universe of the study covers consumers who are older than 18 and living in the central district of Erzurum province. Convenience sampling method was employed. Surveys were carried out in July 2012. 400 survey forms were distributed, and 350 were taken into account after excluding deficient or defective ones. Before collecting data by preparing the definitive survey form, 20 people were interviewed to see whether or not the questions were comprehended. Accordingly, the questions were re-organized. The survey form covers 4 types of questions. The 1st type deals with questions about demographic characteristics. The 2 nd group deals with life style. The 3 rd group deals

Inquipy 2015/2 
with attitudes and knowledge levels regarding environment. The 4 th group measures sustainable consumption. The scales regarding sustainable consumption were prepared based on the scales of Şener and Hazar (2007) and Flaj and Martinez (2006); the scales regarding the knowledge level about environment were prepared based on Haron and et al. (2005); and the attitude towards environmental protection was measured based on Oliver (2007), Ginsberg and Bloom (2004), and Kaiser and et al. (1999). Life style variables are VALS2 variables specified by the Stanford Research Institute. Agreement levels regarding the expressions about life style and sustainable consumption were specified based on a 5 -point Likert-type scale ( $5=\mathrm{I}$ strongly agree, $1=\mathrm{I}$ strongly disagree; $1=\mathrm{I}$ know it well, $5=\mathrm{I}$ have no idea). SPSS 11.0 was used to conduct analyses.

\subsection{Data Analysis and Hypotheses Test Results}

\subsubsection{DemographicCharacteristics of Respondent}

$55 \%$ of the participants were male, and $45 \%$ were female. $25 \%$ had an income TL 1000 and under TL 1000; 14\% between TL 1001 and 2000; 27\% between TL 2001 and 3000; 26\% between TL 3001 and 4000; and $8 \%$ had an income higher than TL 4001.In terms of education level, $\% 15$ have primary education, $\% 40$ have secondary education, $\% 45$ have higher education. $\% 62$ of the participants were civil servant, $\% 15$ were students, $\% 12$ private sector employee, $\% 5$ employee, \%3'ü tradesmanand \%3’ü housewife.

\subsubsection{The Knowledge Levels and the Attitudes of the Respondents Regarding Sustainable Consumption and Environment}

\section{0}

Inquipy $2015 / 2$

In order to reveal the environmental knowledge levels of the respondents, environmental problems were listed, and the respondents were asked whether or not they knew them. The relevant results are shown in Table 1.

According to the results, the respondents have the highest level of knowledge on "struggle against the destruction of forests", "protection of water resources", and "global warming" while they have the lowest level of knowledge on greenhouse effect. In order to determine the respondents' attitudes towards the protection of the environment, the results shown in Table 2 were derived from their statements. 
Table 1: Knowledge Level of Environmental Problems

\begin{tabular}{|l|l|l|l|l|l|}
\hline $\begin{array}{l}\text { Environmental } \\
\text { problems }\end{array}$ & Mean & $\begin{array}{l}\text { Std. } \\
\text { Deviation }\end{array}$ & $\begin{array}{l}\text { Environmental } \\
\text { problems }\end{array}$ & Mean & $\begin{array}{l}\text { Std. } \\
\text { Deviation }\end{array}$ \\
\hline $\begin{array}{l}\text { Solid waste } \\
\text { problem }\end{array}$ & 2.5017 & 0.95437 & $\begin{array}{l}\text { Greenhouse gas } \\
\text { effect }\end{array}$ & 2.9867 & 1.08620 \\
\hline $\begin{array}{l}\text { Combating } \\
\text { deforestation }\end{array}$ & 2.1860 & 0.88239 & Global warming & 2.3612 & 1.03116 \\
\hline $\begin{array}{l}\text { Protection of } \\
\text { water resources }\end{array}$ & 2.2282 & 0.89160 & $\begin{array}{l}\text { Depletion of the } \\
\text { ozone layer }\end{array}$ & 2.4567 & 0.97713 \\
\hline $\begin{array}{l}\text { Organic } \\
\text { farming } \\
\text { methods }\end{array}$ & 2.6578 & 1.02592 & $\begin{array}{l}\text { Effect of } \\
\text { chemical matter }\end{array}$ & 2.5083 & 0.99537 \\
\hline
\end{tabular}

$1=\mathrm{I}$ know it well, $5=\mathrm{I}$ have no idea.

Table2:Attitudes Towards Environmental Protection

\begin{tabular}{|l|l|l|}
\hline Expressions Toward Environmental Protection & Mean & Std.Deviation \\
\hline $\begin{array}{l}\text { We have to think dangers that lead to environmental } \\
\text { pollution. }\end{array}$ & 1.3144 & 0.60676 \\
\hline $\begin{array}{l}\text { It is important to purchase environmentally friendly } \\
\text { products. }\end{array}$ & 1.3980 & 0.59340 \\
\hline $\begin{array}{l}\text { While we buy a product, it is important to consider } \\
\text { how this affects others }\end{array}$ & 1.5681 & 0.74354 \\
\hline $\begin{array}{l}\text { Agriculture drugs applied to food that we eat is } \\
\text { polluting the environment. }\end{array}$ & 1.6611 & 0.87832 \\
\hline $\begin{array}{l}\text { It is important to buy recycled products such as } \\
\text { paper, glass and plastic. }\end{array}$ & 1.5686 & 0.78601 \\
\hline $\begin{array}{l}\text { I think that people dont have enough effort to protect } \\
\text { environment }\end{array}$ & 1.5249 & 0.84669 \\
\hline $\begin{array}{l}\text { I think people aren't informed enough about the } \\
\text { environment }\end{array}$ & 1.5914 & 0.83813 \\
\hline $\begin{array}{l}\text { Even our welfare level decreased we must continue to } \\
\text { act environmentally friendly. }\end{array}$ & 1.4718 & 0.66586 \\
\hline $\begin{array}{l}\text { None of the economic problem makes it necessary to } \\
\text { act environment ruthlessly }\end{array}$ & 1.5183 & 0.81884 \\
\hline
\end{tabular}

1= I strongly agree, 5= I strongly disagree

According to the results, the respondents mostly agree with the expressions "considering the threats towards environmental pollution", "purchasing environment-friendly products", and "maintaining the environmental attitude even if it has a negative influence on one's welfare". Afterwards, the respondents were asked whether or not they knew anything about sustainable consumption, and the results are given in Table 3. 
Table 3: Recognation Level of Sustainable Consumption Word

\begin{tabular}{|l|l|l|}
\hline How do you know sustainable consumption? & Frequences & $\%$ \\
\hline Very & 73 & 24 \\
\hline Middle & 131 & 41 \\
\hline Some & 85 & 25 \\
\hline None & 32 & 10 \\
\hline Total & 321 & 100 \\
\hline
\end{tabular}

The results indicate that the respondents are moderately familiar with sustainable consumption. In order to reveal whether what they knew about sustainable consumption was accurate or not, various expressions defining sustainable consumption were given, and the respondents were asked to mark the ones they agreed with. The results are indicated in Table 4.

Table 4: Sustainable Consumption Description

\begin{tabular}{|l|l|l|}
\hline Sustainable Consumption; & Frequences & $\%$ \\
\hline $\begin{array}{l}\text { It is the economic growth to meet the demands at the } \\
\text { expense of ignoring environmental protection. }\end{array}$ & 78 & 24 \\
\hline $\begin{array}{l}\text { It is a kind of development which supports individuals to } \\
\text { live according to their mentality of quality life. }\end{array}$ & 126 & 39 \\
\hline $\begin{array}{l}\text { It is a kind of consumption meeting the current demands } \\
\text { without threatening the possibility of meeting the demands } \\
\text { of next generations. }\end{array}$ & 80 & 25 \\
\hline $\begin{array}{l}\text { It is a kind of growth which sustains long-term increase in } \\
\text { the services provided and the goods produced as well as a } \\
\text { rise in their quality. }\end{array}$ & 37 & 12 \\
\hline Total & 321 & 100 \\
\hline
\end{tabular}

According to the results, the respondents chose the expression

of "It is a kind of development which supports individuals to live according to their mentality of quality life." at the rate of $39 \%$. The expression which accurately defines sustainable consumption, "It is a kind of consumption meeting the current demands without threatening the possibility of meeting the demands of next generations." was chosen at the rate of $25 \%$. It is clear that at least a certain proportion of the respondents defined sustainable consumption accurately. How the respondents define their attitudes towards sustainable consumption are shown in Table 5 . 
Table 5: Attitudes Towards Sustainable Consumption

\begin{tabular}{|l|l|l|}
\hline Sustainable consumption; & Frequences & $\mathbf{( \% )}$ \\
\hline I support sustainable consumption until the end. & 102 & 31 \\
\hline I think positive. & 145 & 45 \\
\hline $\begin{array}{l}\text { If others want to take care of sustainabla consumption it is } \\
\text { not mind for me }\end{array}$ & 47 & 15 \\
\hline I don't care. & 12 & 4 \\
\hline I think it is a waste of time and energy. & 15 & 5 \\
\hline Total & 321 & 100 \\
\hline
\end{tabular}

According to the results, $45 \%$ of the respondents have positive opinions on sustainable consumption while $31 \%$ support it. In order to reveal the sustainable consumption tendencies of respondents, descriptive statistics, which were obtained according to the responses given to sustainable consumption behaviors, are given in Table 6. Initially, the alpha coefficient of the scale was evaluated. After excluding 1 variable which was not fit, the scale reached an acceptable value. Therefore, 10 variables were included in the study. The alpha coefficient of the sustainable consumption scale is $\alpha=0.80$.

Table 6: Descriptive Statistics of Sustainable Consumption Scale

\begin{tabular}{|l|l|l|}
\hline Sustainable Consumption Scale; & Mean & $\begin{array}{l}\text { Std. } \\
\text { Deviation }\end{array}$ \\
\hline $\begin{array}{l}\text { I use public transport instead of my personal car for } \\
\text { transportation. }\end{array}$ & 2,54 & 1,26 \\
\hline $\begin{array}{l}\text { I turn off devices like music player when I do not use } \\
\text { them. }\end{array}$ & 1,51 & 0,77 \\
\hline $\begin{array}{l}\text { I turn off electronical gadgets instead of keeping them in } \\
\text { standby mode. }\end{array}$ & 1,70 & 0,89 \\
\hline $\begin{array}{l}\text { I pay attention to purchasing products with recyclable } \\
\text { packets. }\end{array}$ & 2,06 & 0,94 \\
\hline I always follow publications on environment. & 2,42 & 1,02 \\
\hline I try to reduce water usage as much as possible. & 2,06 & 1,06 \\
\hline I rent the products instead of purchasing them. & 3,21 & 1,19 \\
\hline I repair the old one before buying something new. & 2,21 & 1,13 \\
\hline I benefit from the products until they get battered. & 1,89 & 0,94 \\
\hline I try to purchase organic products while shopping. & 2,04 & 1,06 \\
\hline
\end{tabular}

1= I strongly agree, 5= I strongly disagree

According to the mean scores, the respondents engage in sustainable consumption mostly by turning off music players when not used, turning off electronical gadgets instead of keeping them in stand-by 
mode, and benefiting from the products until they get battered.

\subsubsection{Lifestyle Model Test}

Before testing the relationships of the variables of the research model, the validity of the VALS2 scale for the sample was tested. The scale was subjected to factor analysis. According to the reliability analysis results, 13 variables were excluded, and 21 variables were included in the factor analysis. The alpha coefficient was found to be 0.8305 . As a result of the factor analysis on variables, 5 factors were obtained with eigenvalues higher than 1 . Of the variables, the ones with a factor loading of not less than 0.40 were taken into account. These factors explain $55.75 \%$ of the total variance (KMO sampling adequacy: $81.4 \%$, Bartlett's Sphericity test: 2098.070, p<0.000). Table 7 shows the relevant results.

Table 7: Factor of VALS Scale

\begin{tabular}{|l|l|l|l|}
\hline Variables & Factor Loading & $\begin{array}{l}\text { Variance } \\
\%\end{array}$ & $\begin{array}{l}\text { Eigen } \\
\text { Value }\end{array}$ \\
\hline Factor 1: Experincers $\alpha=0,81$ & & 14,27 & 3,14 \\
\hline 9. I often crave excitement. & 0,743 & & \\
\hline $\begin{array}{l}\text { 22. I Iike a lot of excitement in my } \\
\text { life }\end{array}$ & 0,736 & & \\
\hline $\begin{array}{l}\text { 27.I like the challenge of doing } \\
\text { something I have never done } \\
\text { before. }\end{array}$ & 0,724 & & \\
\hline 30. I am always looking for a thrill. & 0,702 & & \\
\hline $\begin{array}{l}\text { 31. I like doing things that are new } \\
\text { and different }\end{array}$ & 0,751 & & \\
\hline Factor 2: Strivers $\alpha=0,82$ & 0,619 & 13,66 & 3,06 \\
\hline $\begin{array}{l}\text { 5.I follow the latest trends and } \\
\text { fashion }\end{array}$ & 0,786 & & \\
\hline $\begin{array}{l}\text { 12.. I dress more fashionably than } \\
\text { most people. }\end{array}$ & 0,506 & & \\
\hline $\begin{array}{l}\text { 16.I must admit that I like to show } \\
\text { off. }\end{array}$ & 0,838 & 10,67 & 2,35 \\
\hline $\begin{array}{l}\text { 19.I like to dress in the latest } \\
\text { fashions }\end{array}$ & 0,838 & & \\
\hline $\begin{array}{l}\text { 25.I want to be considered } \\
\text { fashionable. }\end{array}$ & 0,644 & & \\
\hline Factor 3: Innovators $\alpha=0,67$ & \begin{tabular}{l} 
\\
\hline $\begin{array}{l}\text { 2.I like extraordinary people and } \\
\text { things }\end{array}$
\end{tabular} & & \\
\hline
\end{tabular}




\begin{tabular}{|l|l|l|l|}
\hline 3. I like trying new things. & 0,563 & & \\
\hline $\begin{array}{l}\text { 14.I have more ability than most } \\
\text { people. }\end{array}$ & 0,695 & & \\
\hline $\begin{array}{l}\text { 15.I consider myself an } \\
\text { intellectual. }\end{array}$ & 0,679 & 9,25 & 2,03 \\
\hline Factor 4: Believers $\alpha=0,66$ & & & \\
\hline $\begin{array}{l}\text { 13. The federal government should } \\
\text { encourage prayers in public } \\
\text { schools. }\end{array}$ & 0,819 & & \\
\hline $\begin{array}{l}\text { 20. There is too much sex on } \\
\text { television today }\end{array}$ & 0,757 & & \\
\hline 21.I like to lead others. & 0,502 & & \\
\hline $\begin{array}{l}\text { 26.If a woman provides a happy } \\
\text { life for her family she can take a } \\
\text { accomplished life. }\end{array}$ & 0,611 & 7,87 & \\
\hline Factor 5: Thinkers $\alpha=0,65$ & 0,744 & & \\
\hline $\begin{array}{l}\text { 8.I like to learn about art, culture, } \\
\text { and history. }\end{array}$ & 0,617 & & \\
\hline $\begin{array}{l}\text { 33.I would like to understand } \\
\text { more about how the universe } \\
\text { works. }\end{array}$ & 0,744 & & \\
\hline $\begin{array}{l}\text { 34.I want my life to be getting } \\
\text { better. }\end{array}$ & 0,740 & & \\
\hline
\end{tabular}

The obtained factors were not completely compliant with the VALS2 factors. However, there were 8 VALS2 factors. 5 factors were obtained in this study.

\subsubsection{Testing Research Hypotheses}

Multiple regression analysis was carried out to test research hypotheses. Table 8 shows the relevant results. Firstly, the influence of life styles on environmental knowledge and attitude towards environment was explored. Afterwards, the influences of all the variables on sustainable consumption were explored. 
Table 8: Regression Coefficients and Anova Test Results of Research Model

\begin{tabular}{|c|c|c|c|c|c|}
\hline \multirow{2}{*}{$\begin{array}{l}\text { Depent } \\
\text { Variable:İnformantion of } \\
\text { environment } \\
\text { Independent Var: Lifestyle }\end{array}$} & \multirow{2}{*}{$\begin{array}{l}\mathbf{R} \\
0,273 \\
\end{array}$} & \multirow{2}{*}{$\begin{array}{l}\mathbf{R} 2 \\
0,075 \\
\end{array}$} & \multirow{2}{*}{$\begin{array}{l}\text { Adjusted } \\
\text { R2 } \\
0,059 \\
\end{array}$} & \multicolumn{2}{|c|}{ Durbin-Watson } \\
\hline & & & & 1,639 & \\
\hline ANOVA & $\begin{array}{l}\text { Sum of } \\
\text { Squares }\end{array}$ & Sd. & $\begin{array}{l}\text { Mean } \\
\text { Square }\end{array}$ & $\mathbf{F}$ & Sig. \\
\hline Regresion & 12.064 & 5 & 2.413 & 4.753 & 0.000 \\
\hline Residual & 149.757 & 295 & 0.508 & & \\
\hline Total & 161.821 & 300 & & & \\
\hline \multirow{3}{*}{$\begin{array}{l}\text { Depent Variable: Attitudes } \\
\text { towards environment } \\
\text { Independent: Lifestyle }\end{array}$} & & & & & \\
\hline & $\mathbf{R}$ & $\mathbf{R} 2$ & $\begin{array}{l}\text { Adjusted } \\
\text { R2 }\end{array}$ & \multicolumn{2}{|c|}{ Durbin-Watson } \\
\hline & 0.409 & 0.167 & 0.153 & 1,951 & \\
\hline ANOVA & $\begin{array}{l}\text { Sum of } \\
\text { Squares }\end{array}$ & Sd. & $\begin{array}{l}\text { Mean } \\
\text { Square }\end{array}$ & $\mathbf{F}$ & Sig. \\
\hline Regresion & 11.806 & 5 & 2.361 & 11.840 & 0.000 \\
\hline Residual & 58.833 & 295 & 0.199 & & \\
\hline Total & 70.640 & 300 & & & \\
\hline \multirow{3}{*}{$\begin{array}{l}\text { Depent Variable: } \\
\text { Sustainable Consumption } \\
\text { Independent: Lidestyle, } \\
\text { Informantion of } \\
\text { environment, Attitudes } \\
\text { towards environment. }\end{array}$} & & & & & \\
\hline & $\mathbf{R}$ & R2 & $\begin{array}{l}\text { Adjusted } \\
\text { R2 } \\
\end{array}$ & \multicolumn{2}{|c|}{ Durbin-Watson } \\
\hline & 0.461 & 0.212 & 0.194 & 1,670 & \\
\hline ANOVA & $\begin{array}{l}\text { Sum of } \\
\text { Squares }\end{array}$ & Sd. & $\begin{array}{l}\text { Mean } \\
\text { Square }\end{array}$ & $\mathbf{F}$ & Sig. \\
\hline Regresion & 24.184 & 7 & 3.455 & 11.291 & .000 \\
\hline Residual & 89.655 & 293 & .306 & & \\
\hline Total & 113.840 & 300 & & & \\
\hline
\end{tabular}

According to the first model results, life styles explain $7 \%$ of environmental knowledge. Life styles explain 16\% of environmental attitude, according to the second model. The influence of life styles, environmental knowledge, and environmental attitude on sustainable consumption was $21 \%$ according to the last model. Table 9 shows Beta values of the variables in the models and their signifiance levels. 
Table 9: Beta Values of Research Model's Factors

\begin{tabular}{|c|c|c|c|c|c|}
\hline \multirow{2}{*}{$\begin{array}{l}\text { Depent Variable: } \\
\text { Information of } \\
\text { environment }\end{array}$} & \multicolumn{2}{|c|}{$\begin{array}{c}\text { Unstandardized } \\
\text { Coefficients }\end{array}$} & $\begin{array}{l}\text { Standardized } \\
\text { Coefficient }\end{array}$ & \multirow[t]{2}{*}{ TValue } & \multirow[t]{2}{*}{ Sig. } \\
\hline & B & $\begin{array}{c}\text { Std. } \\
\text { Errors }\end{array}$ & Beta & & \\
\hline Constant & 2.025 & 0.205 & & 9.877 & 0.000 \\
\hline Experiencers & -0.111 & 0.059 & -0.124 & -1.882 & 0.061 \\
\hline Strivers & -0.053 & 0.051 & -0.067 & -1.037 & 0.301 \\
\hline Innovators & 0.269 & 0.063 & 0.277 & 4.283 & 0.000 \\
\hline Believers & 0.016 & 0.056 & 0.017 & 0.289 & 0.773 \\
\hline Thinkers & 0.113 & 0.073 & 0.090 & 1.550 & 0.122 \\
\hline \multirow{2}{*}{$\begin{array}{l}\text { Depent Variable: } \\
\text { Attitudes towards } \\
\text { the environment }\end{array}$} & \multicolumn{2}{|c|}{$\begin{array}{l}\text { Unstandardized } \\
\text { Coefficients }\end{array}$} & $\begin{array}{c}\text { Standardized } \\
\text { Coefficient }\end{array}$ & \multirow[t]{2}{*}{ T Value } & \multirow[t]{2}{*}{ Sig. } \\
\hline & B & $\begin{array}{c}\text { Std. } \\
\text { Errors }\end{array}$ & Beta & & \\
\hline Constant & 0.863 & 0.129 & & 6.712 & 0.000 \\
\hline Experiencers & -0.012 & 0.037 & -0.020 & -.322 & 0.748 \\
\hline Strivers & -0.033 & 0.032 & -0.062 & -1.017 & 0.310 \\
\hline Innovators & 0.085 & 0.039 & 0.132 & 2.152 & 0.032 \\
\hline Believers & 0.035 & 0.035 & 0.055 & 0.989 & 0.323 \\
\hline Thinkers & 0.299 & 0.046 & 0.361 & 6.556 & 0.000 \\
\hline \multirow{2}{*}{$\begin{array}{l}\text { Depent Variable: } \\
\text { Sustainable } \\
\text { Consumption }\end{array}$} & \multicolumn{2}{|c|}{$\begin{array}{l}\text { Unstandardized } \\
\text { Coefficients }\end{array}$} & $\begin{array}{l}\text { Standardized } \\
\text { Coefficient }\end{array}$ & \multirow[t]{2}{*}{ T Value } & \multirow[t]{2}{*}{ Sig. } \\
\hline & B & $\begin{array}{c}\text { Std. } \\
\text { Errors }\end{array}$ & Beta & & \\
\hline Constant & 0.717 & 0.189 & & 3.794 & 0.000 \\
\hline Experiencers & 0.071 & 0.046 & 0.094 & 1.540 & 0.125 \\
\hline Strivers & -0.006 & 0.040 & -0.009 & -0.147 & 0.883 \\
\hline Innovators & -0.005 & 0.050 & -0.007 & -0.107 & 0.915 \\
\hline Believers & 0.120 & 0.044 & 0.148 & 2.752 & 0.006 \\
\hline Thinkers & 0.111 & 0.060 & 0.106 & 3.501 & 0.001 \\
\hline $\begin{array}{l}\text { Information about } \\
\text { environment }\end{array}$ & 0.205 & 0.046 & 0.245 & 4.445 & 0.000 \\
\hline $\begin{array}{l}\text { Attitudes towards } \\
\text { the environment }\end{array}$ & 0.253 & 0.074 & 0.200 & 3.436 & 0.001 \\
\hline
\end{tabular}

According to the first model, which explores the influence of life styles on environmental knowledge, there is a relationship between innovators and environmental knowledge. People with innovator life style know more about environment. According to the second model, 
which explores the influence of life styles on environmental attitude, the life styles of innovators and thinkers are statistically significant. In other words, innovators and thinkers have positive attitudes towards environment. According to the model exploring the influence of life styles, environmental knowledge, and environmental attitude on sustainable consumption, environmental knowledge and attitude towards environmental protection have an influence on sustainable consumption. Believers engage in sustainable consumption more compared to the others. In this way, the research hypotheses;

$\mathrm{H1}$ : Consumer lifestyle is effective on information about environment. $\mathrm{H} 2$ : Consumer lifestyle is effective on attitudes towards the environment.

H3: Information about environment is effective on sustainable consumption

H4: Attitudes towards the environment is effective on sustainable consumption

H5: Consumer lifestyle is effective on sustainable consumption, hypotheses have been accepted.

\section{CONCLUSIONS AND RECOMMENDATIONS}

Using environment and natural resources properly is important for the future of the world. It is not only governments, managements, and businesses that have to be environmentally conscious. Important steps can be taken with the support of consumers, who are the most important driving force of markets. Therefore, all kinds of information are needed to contribute to sustainable consumption. In this study focusing on the influence of life styles, environmental knowledge, and environmental attitude on sustainable consumption, the following results were obtained:

Majority of the participants had intermediate to high educational levels. Most of the participants were civil servants with an income ranging between TL 1001 and 3000. There were both male and female participants. As to the environmental problems, the respondents had the highest knowledge on destruction of forests, protection of water resources, and global warming. As to the attitudes to environmental protection, the respondents mostly agreed with considering threats of pollution, purchasing environmentfriendly products, and maintaining environmental attitude even if it has an influence on welfare. The respondents expressed that they 
were moderately informed about sustainable consumption. In order to determine whether or not what the respondents knew about sustainable consumption was accurate, various expressions defining sustainable consumption were given. According to the results, only a limited number of the respondents (25\%) know the expression which accurately defines sustainable consumption (It is a kind of consumption meeting the current demands without threatening the possibility of meeting the demands of next generations.). The majority of the respondents thinks positively about and support sustainable consumption. The respondents mostly engage in sustainable consumption by turning off music player when not used, turning off electronical gadgets instead of keeping them in stand-by mode, and using the products until they get battered. The life styles of the respondents were measured by VALS2, and 5 life styles were obtained: experiencers, strivers, innovators, believers, and thinkers. Life styles have an influence on environmental knowledge and attitude. Innovators know more about environment. Similarly, innovators and thinkers have positive attitudes towards environment. Environmental knowledge, environmental attitude, and life styles have influence on sustainable consumption. People with environmental knowledge and positive attitudes tend to engage in sustainable consumption. Moreover, believers have higher tendencies for sustainable consumption.

The linear relationship between having positive attitude towards environment and sustainable consumption is consistent with the findings of previous studies (Ginsberg and Bloom, 2004; Özkul 2008; Kımıloğlu 2008). As consumer knowledge on environment increases, they tend to have environment-friendly attitudes and behaviors, which has a positive influence on sustainable consumption. From the perspective of life styles, innovators are the group with the highest environmental knowledge and thus they have positive attitudes towards environment. Thanks to their inquisitive qualities, innovators are knowledgeable and sophisticated people. They follow new ideas and technology. They are interested in social events. Thus, it is clear that they know much about environmental protection. Thinkers value order, knowledge, and responsibility. They are mature, content, relaxed, and calm people. Majority of them make comprehensive research before making decisions on any issue. They make use of the opportunities to enhance their knowledge. Accordingly, they have a tendency to protect the environment even though they do not know

Inquipy

2015/2

149 
as much as innovators. Believers and thinkers engage in sustainable consumption more than others. Believers are conservative people attached to familiar attitudes and behaviors as well as traditions. They obey familial, religious, social, and national rules. They are active in their families, homes, and social and religious organizations to which they have a membership. It is possible that the segment of believers engages in sustainable consumption more in social and moral terms. However, thinkers are interested in world affairs as well as the events in their countries. Therefore, they may spend effort for sustainable development and consumption, which has been one the most important issues of recent times.

Based on the obtained results, recommendations below may be provided:

Majority of the consumers have limited knowledge on environment and environmental problems. Though the consumers have positive attitudes towards environment, their knowledge on sustainable consumption is either incorrect or deficient. It was seen that the consumers' knowledge level on environmental problems is higher than that on sustainable consumption. Majority of the consumers misunderstood sustainable consumption. Governments or various organizations are not only responsible authorities regarding this issue. Companies which have a positive image and reputation among the consumers may participate in activities supporting environment and draw the attention of the consumers. They can be helpful in creating an awareness regarding the issue. As it is the case in the whole world, many companies sponsor various social, environmental, and public events in Turkey. Or, they transfer certain amount of their income to such activities by engaging in goal-oriented marketing. However, as stated in the consumer behavior literature, consumers are informed prior to behaving and develop their attitudes accordingly. Therefore, creating awareness among consumers with all the means of promotion and communication will be helpful in raising knowledge levels.

When sustainable consumption was considerd in terms of life styles, the results supporting the above-mentioned recommendations were obtained. Thinkers and believers engage in sustainable consumption more. Thinkers are inquisitive and interested people who are looking for information. Therefore, they know about the greatest problem of our world: environmental problems and 
sustainable consumption. They are active in such issues. Believers may adopt such a consumption to avoid exaggeration which is not approved morally by religion. This being the case, businesses may support or recommend sustainable consumption more to increase the customers' contribution to sustainable consumption. For instance, money or discounts may be offered for each environmental practice conducted by consumers (e.g. recycling products' packets, using paper and glass packages). Price arrangements may be made to make them prefer recycled materials and packaging. In addition to financial support, businesses may send messages to consumers on the inner satisfaction gained from being environment-friendly which may result in positive attitudes towards environment.

\section{REFERENCES}

Blackwell, R.D., Paul, W.M., \& James, F. E. (2001). Consumer Behavior.Harcourt College Publishers, Ft. Worth, Texas.

Fraj, E., \&Martinez, E. (2006). "Environmental Values and Lifestyles as Determining Factors of Ecological Consumer Behavior", Journal of Consumer Marketing, 23(3), 133-144.

Ginsberg, M.,\&Paul, B.N. (2004). "Chossing The Right Green Marketing Strategy", MIT Sloan Management Review, 46, 79-84.

Göksu, F. ( 1997), 2. Ulusal Çevre Mühendisleri Kongresi, İstanbul.

Haron, S.A., Paim, L., \&Yahaya, N. (2005). "Toward Sustainable Consumption: An Examination Of Environmental Knowledge Among Malaysians", International Journal Of Consumer Studies, 29(2), 1-8.

Kaiser, F.G.,\&Shimoda,T. A. (1999). "Responsibility As A Predictor Of Ecological Behaviour" Journal of Environmental Psychology, 19, 243-253.

Kesic, T.,\&Sunçana,P.R. (2003). "Market Segmentation on the Basis of Food-Related Lifestyles of Croatian Families", British Food Journal, 105(3), 162-174.

Kımıloğlu, H. (2008). "Sürdürülebilir Tüketim Ve Tüketimde Sadeleşmenin Bir Yaşam Biçimi Olarak Benimsenmesi: Kentli Çalışan Kesim Üzerine Bir Araştırma", 13. Ulusal Pazarlama Kongresi içinde (s.147-162), Adana: Çukurova Üniversitesi.

Laroche, M., Bergerson, J.,\&Barbaro-Farleo,G. (2001). "Targeting Consumer Who are Wiiling To Pay More For A Environmentelly Friendly Product", Journal of Consumer Studies, 29(2), 1-8.

Lin, F. (2003). "An Analysis of Hospitality Consumer Lifestyles in the United States", Texas Tech University, PhD Dissertation, USA, UMI. Marketing. 
Odabaşı, Y., \& G. Barış (2002), Tüketici Davranışı, Kapital Medya A.Ş., 2. Baskı, İstanbul.

Oliver, J. (2007). Increasing The Adaption Of Environmentally Frienly Products: Who Are The Non-Adapters, And What Will Get Them To Buy Green?, Postgraduate Dissertation, University Of Rhode Island

Özkul, E. (2010). "Tüketicilerin Değer Yapıları, Gönüllü Sade Yaşam Tarzı ve Sürdürülebilir Tüketim Etkisi”, Dokuz Eylül Üniversitesi”, İşletme Bölümü, 28(2).

Pearce, D.W., \&Warford, J.J. (1993). World Without End. Oxford Üniversity Pres.

Piirto, R. (1991). "VALS The Second Time”. American Demographics, July, 13(7), 6.

Schaefer, A., \&Andrew, C. (2005). "Adressing Sustainability and Consumption", Journal of macromarketing, Vol.25, No.1, pp.76-92.

Şener, A., \&Hazer, O. (2007). "Değerlerin Kadınların Sürdürülebilir Tüketim Davranışı Üzerindeki Etkilerine İlişkin Bir Araştırma”, Hacettepe Üniversitesi

Sosyolojik Araştırmalar (12 Nisan 2008). http://www.sdergi.hacettepe.edu.tr/ De.pdf

Straughan, R, D., \&Robert,J. A. (1999)."Environmental Segmentation Alternatives: A Look At Gren Consumer Behavior in The New Millennium”, Journal of Consumer Marketing, 16(6), 558-575.

Sürdürülebilir Tüketim ve Üretim 10 yıllık Eylem Çerçevesi -Marakeş Süreci.

Zimmer, M.R., Stafford, T.M., \&M.R. Stafferd (1994). "Gren Issues: Dimensions of Environmental Concern”, Journal of Business Research, 30(1), 63-74.

Strategicbusinessinsights.(06.07.2012).http://www.strategicbusinessinsights.com/ vals/about.shtml 